\title{
CHARACTERIZATION OF BIOCHAR FROM RICE HULLS AND WOOD CHIPS PRODUCED IN A TOP-LIT UPDRAFT BIOMASS GASIFIER
}

\author{
A. M. James R., W. Yuan, M. D. Boyette, D. Wang, A. Kumar
}

\begin{abstract}
The objective of this study was to characterize biochar produced from rice hulls and wood chips in a top-lit updraft gasifier. Biochar from four airflows $\left(8,12,16\right.$, or $\left.20 \mathrm{~L} \mathrm{~min}^{-1}\right)$ and two insulation conditions (not insulated or insulated with $88.9 \mathrm{~mm}$ of fiberglass on the external wall of the gasifier) were evaluated. Measurement of elemental composition, higher heating value (HHV), and BET surface area and proximate analyses of the biochar were carried out. It was found that the airflow rate and reactor insulation significantly influenced the chemical composition of the biochar depending on the biomass type. For instance, the carbon content of biochar from rice hulls decreased from $40.9 \%$ to $27.2 \%$ and the HHV decreased from 14.8 to $10.2 \mathrm{MJ} \mathrm{kg}^{-1}$ as the airflow increased from 8 to $20 \mathrm{~L} \mathrm{~min}^{-1}$ when the reactor was insulated. In contrast, the carbon content of biochar from wood chips increased from $82 \%$ to $86 \%$ and the HHV stayed stable at 32.0 to $33.2 \mathrm{MJ}$ $\mathrm{kg}^{-1}$ at the same conditions. Despite these variations, the BET surface area of biochar from both biomass types increased with increased airflow and additional insulation. For example, rice hull biochar had a maximum BET surface area of $183 \mathrm{~m}^{2}$ $\mathrm{g}^{-1}$ at $20 \mathrm{~L} \mathrm{~min}^{-1}$ airflow with insulation. The BET surface of biochar from wood chips peaked at $405 \mathrm{~m}^{2} \mathrm{~g}^{-1}$ at the same conditions.
\end{abstract}

Keywords. Biochar, Biomass, Gasification, Top-lit updraft gasification.

B iochar is usually defined as one of the products of biomass carbonization at temperatures lower than $700^{\circ} \mathrm{C}$ in the absence of oxygen (Lehmann and Joseph, 2009). This carbon-rich material can be widely used in applications such as soil conditioning to improve nutrient retention, adsorption of contaminants in liquid and gas media, and for high-value chemical manufacture (Manya, 2012; Antal and Gronli, 2003). Since biochar production is often performed using pyrolysis processes, extensive literature is available on these production methods (Kammen and Lew, 2005; Trossero, 2008). Some properties of the biomass and reaction parameters have been correlated with the physical and chemical properties of the biochar (Antal et al., 1996; Sun et al., 2014; Demirbas, 2004). This has helped to identify optimum production conditions for biochar in a variety of pyrolysis units. However, despite the

Submitted for review in November 2015 as manuscript number ES 11631; approved for publication by the Energy Systems Community of ASABE in February 2016.

The authors are Arthur M. James R., ASABE Member, Graduate Student, Department of Biological and Agricultural Engineering, North Carolina State University, North Carolina, and Research Associate, Technological University of Panama, El Dorado, Panama; Wenqiao Yuan, ASABE Member, Associate Professor, and Michael D. Boyette, ASABE Member, Professor, Department of Biological and Agricultural Engineering, North Carolina State University, Raleigh, North Carolina; Donghai Wang, ASABE Member, Professor, Department of Biological and Agricultural Engineering, Kansas State University, Manhattan, Kansas; Ajay Kumar, ASABE Member, Associate Professor, Department of Biosystems and Agricultural Engineering, Oklahoma State University, Stillwater, Oklahoma. Corresponding author: Wenqiao Yuan, Campus Box 7625, North Carolina State University, Raleigh, NC 27695; phone: 919-515-6742; e-mail: wyuan2@ncsu.edu. advances of biochar production over the last decades, biochar production technologies are found to have low energy efficiencies (Antal et al., 1990; Antal and Gronli, 2003) because of the heat needed for reactions. In pyrolysis units, such heat is provided by external heating elements (Kwapinski et al., 2010) or the combustion of pyrolysis vapors generated during reactions (Garcia-Perez, 2010).

Gasification of biomass has been considered as an alternative to pyrolysis-based biochar production, but the low biochar yield is a major challenge since gasifiers are designed to maximize the yield of gas products (Bridgwater, 2012; Brick and Lyutse, 2010). Several studies have demonstrated the possibility of implementing gasification systems for biochar production (Shackley et al., 2012; Brown, 2009). Qian et al. (2013) produced biochar in a fluidized bed reactor with switchgrass, sorghum biomass, and red cedar. The reaction temperature ranged from $700^{\circ} \mathrm{C}$ to $800^{\circ} \mathrm{C}$ at different equivalent ratios. The results showed that the quality of the biochar was affected by the gasification parameters and the biomass type. However, it was also reported that not all the biochar was recovered because of the inability of the cyclone to retrieve the product. Likewise, most fixed bed reactors might also present challenges for the production of biochar because of the temperature instability within the gasification bed, which can generate hot spots of exothermal reactions that lead to large variations in the gasification products (Warnecke, 2000). As result, current gasification technologies require modifications in order to be implemented for biochar production.

Top-lit updraft (TLUD) gasification has been presented as a gasification technology for biochar production (Peterson 
and Jackson, 2014; Huangfu et al., 2014). Relatively high yield of biochar, parallel production of syngas, and the generation of exothermal heat for gasification and pyrolysis reactions are some of the advantages of implementing TLUD gasification for biochar production (Birzer et al., 2013; Tryner et al., 2014). Thus far, small-scale TLUD gasifiers have proven to be an effective alternative to common woodstoves in developing countries (Mukunda et al., 2010). For such applications, it was found that reduced amounts of smoke and other contaminants were emitted from the cookstove (Birzer et al., 2013; Reed and Larson, 1997). This is because of the combustion of volatiles in the reactor to produce biochar and syngas, and then the combustion of syngas produced heat for cooking. The biochar produced in these small TLUD gasifiers might be useful for other applications (Brewer, 2012). However, little is known about the biochar quality since no previous studies of biochar characterization as a function of the available air for gasification and reactor design have been reported to date. Limited information is available to identify other potential applications for the biochar from this process (Brown, 2009). The objective of this research was therefore to study the key properties of biochar from top-lit updraft gasification and correlate such properties with the airflow rate and the use of insulation on the gasifier. This can help to identify variations in chemical and physical properties of the biochar due to changes in the temperature distribution within the gasifier.

\section{MATERIALS AND METHODS}

The experiments were carried out in a top-lit updraft gasifier with $10.1 \mathrm{~cm}$ internal diameter and $152 \mathrm{~cm}$ height. This gasifier was equipped with three thermocouples located at the top, middle, and bottom, as shown in figure 1. A data logger (model UX120-014M, Onset Computer Corp., Bourne, Mass.) recorded the temperatures. Two insulation conditions were used to produce biochar: no insulation or $88.9 \mathrm{~mm}$ of fiberglass insulation on the outside wall of the gasifier. Additionally, airflow rates of $8,12,16$, and $20 \mathrm{~L}$ $\min ^{-1}$ were used for biochar production, which were supplied

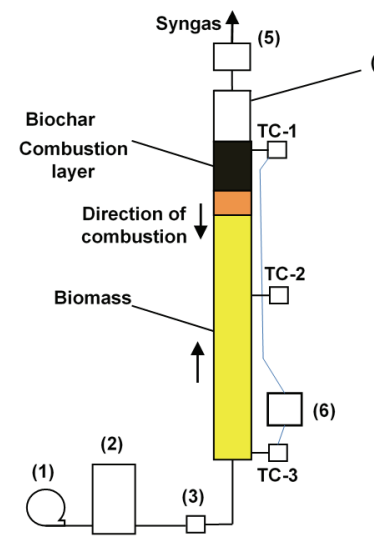

(4) Height: $152 \mathrm{~cm}$ Diameter: $10.1 \mathrm{~cm}$

(1) Air compressor

(2) Reservoir tank

(3) Airflow meter

(4) Top-lit updraft gasifier

(5) Flare

(6) Data logger

TC-\# thermocouple, location from bottom

TC- $1,112.15 \mathrm{~cm}$

TC-2, $51 \mathrm{~cm}$

$\mathrm{TC}-3,4.2 \mathrm{~cm}$

Figure 1. Schematic diagram of top-lit updraft gasifier. by an air compressor (1.5 kW, 8.62 bar max. pressure) equipped with a $22.7 \mathrm{~L}$ reservoir tank (WEN, Elgin, Ill.). Rice hulls from Carolina Greenhouses (Kinston, N.C.) and pine wood chips from a local grinding company (Newton County, N.C.) were used as the feedstocks. The particle size of the rice hulls was measured using different screen sizes; the average particles were smaller than $2 \mathrm{~mm}$. The pine wood chips had particle sizes smaller than $10 \mathrm{~mm}$; particles smaller than $3 \mathrm{~mm}$ were removed using a $3 \mathrm{~mm}$ screen. The final particle size of the wood chips ranged between 3 and $10 \mathrm{~mm}$. The equivalent superficial velocities and air-fuel equivalence ratios for the two biomass types at both insulation conditions are listed in table 1.

The main properties of the two biomass types are presented in table 2. Elemental compositions of biomass and biochar were measured in a CHNS/O elemental analyzer (model 2400, Perkin Elmer, Waltham, Mass.). Volatile matter content was determined based on ASTM Standard D3175-11 (ASTM, 2011). Ash content was determined following ASTM Standard E1755-01 (ASTM, 2015). Fixed carbon was calculated based on the percentage difference in volatile matter, ash, and moisture. In addition, the higher heating value (HHV) was determined for the two biomass types and all biochar samples. This analysis was carried out in a bomb calorimeter (C 200, IKA-Werke GmbH and Co., Staufen, Germany) with benzoic acid as the standard. The BET surface area of the samples was measured with a surface area analyzer (Autosorb-1C, Quantachrome, Boynton Beach, Fla.) operated under isothermal nitrogen sorption. All samples were degassed for $12 \mathrm{~h}$ at $250^{\circ} \mathrm{C}$ under vacuum before BET analysis. The recorded chemical properties of the biochar were statistically analyzed to identify differences in the effect of the airflow, insulation condition, and biomass type. The GLM procedure in SAS, corrected with Tukey's HSD (honestly significant difference), was used with a confidence level of $90 \%$.

\section{RESULTS AND DISCUSSION REACTION TEMPERATURES}

The increase in combustion temperature in the TLUD gasifier was positively correlated with airflow, as shown in

Table 2. Elemental composition of rice hulls and wood chips.

\begin{tabular}{ccc}
\hline & \multicolumn{2}{c}{ Biomass } \\
\cline { 2 - 3 } & Rice Hulls & Wood Chips \\
\hline C (\%) & 36.99 & 47.90 \\
H (\%) & 5.14 & 1.70 \\
N (\%) & 0.58 & 0.30 \\
Oa (\%) & 56.30 & 49.90 \\
S (\%) & 1.0 & 0.20 \\
Ash (\%) & 23.78 & 0.57 \\
Volatile matter (\%) & 58.17 & 74.92 \\
Fixed carbon (\%) & 9.57 & 16.66 \\
Moisture (\%) & 8.48 & 7.85 \\
HHV (MJ kg $\left.{ }^{-1}\right)$ & 14.42 & 19.53 \\
Particle size (mm) & $X \leq 2$ & $3<X \leq 10$
\end{tabular}

Table 1. Equivalent superficial velocity and air-fuel equivalence ratio at four airflow rates.

\begin{tabular}{|c|c|c|c|c|c|c|c|c|c|}
\hline & & \multicolumn{4}{|c|}{ Without Insulation } & \multicolumn{4}{|c|}{ With Insulation } \\
\hline \multicolumn{2}{|c|}{ Airflow rate $\left(\mathrm{L} \mathrm{min}^{-1}\right)$} & 8 & 12 & 16 & 20 & 8 & 12 & 16 & 20 \\
\hline \multicolumn{2}{|c|}{ Superficial velocity $\left(\mathrm{cm} \mathrm{s}^{-1}\right)$} & 1.66 & 2.50 & 3.33 & 4.16 & 1.66 & 2.50 & 3.33 & 4.16 \\
\hline \multirow[t]{2}{*}{ Equivalence ratio } & Rice hulls & 0.28 & 0.39 & 0.40 & 0.45 & 0.26 & 0.33 & 0.37 & 0.44 \\
\hline & Woodchips & 0.27 & 0.29 & 0.33 & 0.37 & 0.23 & 0.28 & 0.31 & 0.35 \\
\hline
\end{tabular}




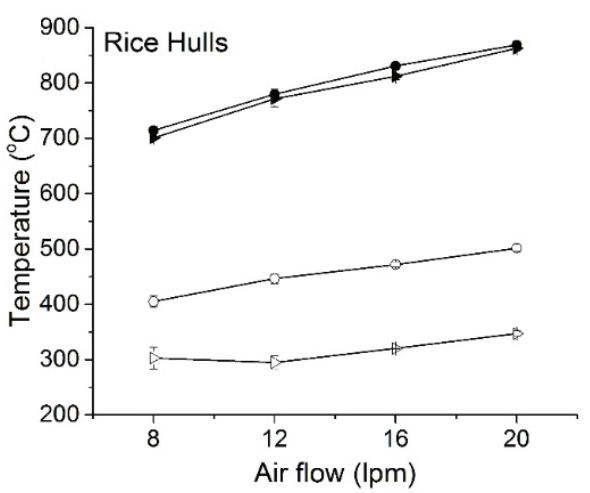

(a)

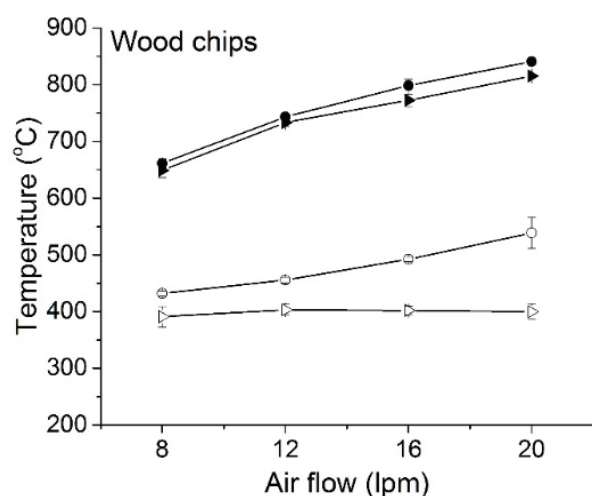

(b)

Figure. 2. Airflow rate and insulation effects on combustion zone temperature and average temperature of TLUD gasification of (a) rice hulls and (b) wood chips: $\triangleright=$ without insulation, $\bullet=$ with insulation, $\triangleright=$ average temperature without insulation, $\circ=$ average temperature with insulation.

figure 2. This tendency was observed for both rice hulls and wood chips, which had different chemical properties (table 1). However, no significant difference in the combustion temperature was noticed when the two insulation conditions were evaluated at all airflow rates. Because the insulation helped to reduce heat loss through the gasifier wall, an increase was observed in the overall temperature in the gasifier with insulation. The highest temperature increase was nearly $154^{\circ} \mathrm{C}$ for rice hulls and $138^{\circ} \mathrm{C}$ for wood chips. The reaction temperature across carbonization units has been found to play a significant role in the final chemical composition and quality of biochar. This is because of the decomposition of different compounds of biomass at different temperatures (Demirbas et al., 2001), which can lead to the formation of different pore arrangements, surface areas, and chemical properties of the biochar (Antal and Gronli, 2003).

\section{ElEMENTAL COMPOSITION OF BIOCHAR}

Figure $3 \mathrm{a}$ shows the elemental carbon content in biochar produced from rice hulls. The carbon content decreased from $40 \%$ to $27 \%$ or $28 \%$ as the airflow increased from 8 to $20 \mathrm{~L}$ $\mathrm{min}^{-1}$, which might be attributed to the increased combustion temperature. Insulation had no significant effect on the elemental carbon content of the biochar. The comparison of the carbon content of the biochar and the initial carbon composition of rice hulls $(36.99 \%)$ reveals that higher carbon content was achieved after the carbonization process at lower airflows ( 8 and $12 \mathrm{~L} \mathrm{~min}^{-1}$ ). In contrast, the carbon produced at higher airflows (16 and $20 \mathrm{~L} \mathrm{~min}^{-1}$ ) was significantly

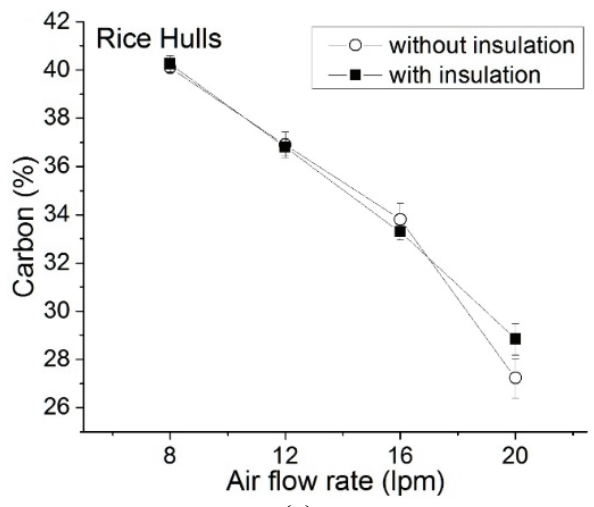

(a) lower than that of the initial biomass. Gasification systems are fueled by the carbon-based materials present in the biomass; thus, the carbon content of the biomass might be reduced depending on the carbonization mechanism during the reactions. Reduction of carbon content has been associated with carbonization due to oxidation of the molecular components of the biomass (Baldock and Smernik, 2002), which can present a more significant impact due to the low organic composition of rice hulls.

In contrast to rice hull gasification, the carbon content of biochar from wood chips increased from $79 \%$ to $85 \%$ without insulation, and from $82 \%$ to $86 \%$ with insulation, with increasing airflow (fig. 3b). For both insulation conditions and all airflows, the carbon content of wood chip biochar was significantly higher than that in the biomass $(47.9 \%)$. This was because oxygen, hydrogen, and nitrogen were detached from the biochar at temperatures above $600^{\circ} \mathrm{C}$, at which point the carbon concentration in the biochar increased (Amonette and Joseph, 2009). The increase in carbon content was also enhanced by the increase in the airflow rate and the addition of insulation, resulting in a higher overall temperature within the gasifier. It is apparent that the trends of carbon content for the two biomass types were opposite regardless of the insulation condition. This phenomenon can be explained by the ash content of these two raw materials. Antal and Gronli (2003) stated that carbonization of biomass with low ash content can increase the carbon content in biochar because of the reduction of weight due to devolatilization. However, this is opposite for biomass with

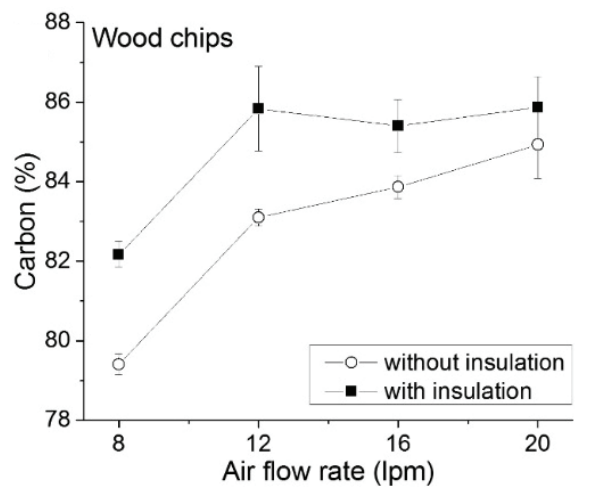

(b)

Figure 3. Elemental carbon composition in biochar produced from (a) rice hulls and (b) wood chips. 
high ash content, which can present decreased carbon content as it is carbonized. The rice hulls in this study contained $23.78 \%$ ash, which was significantly higher than the $0.57 \%$ ash in wood chips (table 1). High amounts of ash represent a partially unchanged amount of ash within the biochar produced during reactions. As result, less carbon-based reactants are available, which reduces the carbon content of the biochar due to carbon conversion in the gasification and combustion reactions (Qian et al., 2013). A similar tendency was observed in the results from a previous study (Peterson and Jackson, 2014), in which corn stover (28\% ash) and wheat straw $(12 \%$ ash) were pyrolyzed at temperatures from $400^{\circ} \mathrm{C}$ to $700^{\circ} \mathrm{C}$. The results showed that the carbon content of the biochar from wheat straw increased from $73 \%$ to $81 \%$, while for corn stover it decreased from $60 \%$ to $58 \%$.

The nitrogen content in the biochar from rice hulls was found to decrease with and without insulation as airflow increased. However, gasification without insulation resulted in higher overall nitrogen content in the biochar than gasification with insulation, as shown in figure 4a. This decrease in nitrogen content with increasing airflow indicated that nitrogen from rice hulls was removed because of the thermochemical degradation of biomass. Nitrogen in biomass materials is represented by amino acids and proteins that are easily converted in thermochemical processes to nitrogen-based chemicals such as ammonia, nitrogen oxides, and molecular nitrogen due to gas-solid reactions at high temperatures (Hu et al., 2008). However, this observation was not true for the wood chip biochar, which showed no significant differences in nitrogen content at all levels of airflow and insulation (fig. 4b).

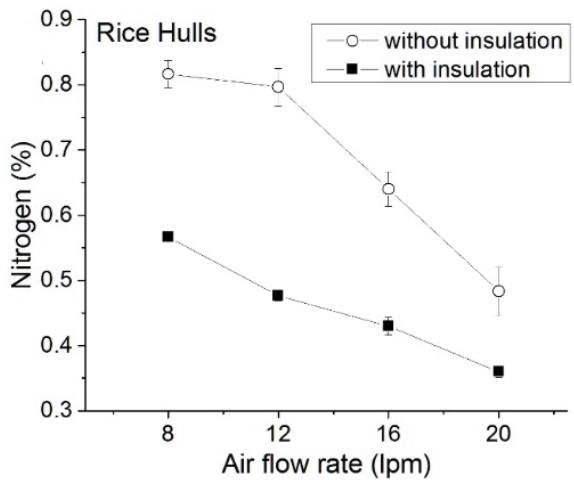

(a)
Figure 5 shows the hydrogen contents of biochar from rice hulls and wood chips. The hydrogen content of biochar from rice hulls decreased as the airflow increased regardless of insulation. However, significantly higher hydrogen content in the biochar was found at lower airflows $\left(8\right.$ and $\left.12 \mathrm{~L} \mathrm{~min}^{-1}\right)$ when the reactor was not insulated, implying that a lower overall temperature within the gasifier can generate higher hydrogen content. This reduction in the hydrogen content can be attributed to dehydration, dehydrogenation, and cracking of hydrogen binding chains within the biochar that can be induced by increasing the reaction temperature (Kim et al., 2012; Baldock and Smernik, 2002). A similar pattern was found in the hydrogen content of biochar from wood chips with no insulation. Likewise, a decrease in hydrogen content with increasing reaction temperature was reported by Demirbas (2004), who studied the pyrolysis of corncob, olive husk, and tea wastes and found that the hydrogen content of biochar decreased from approximately $5.5 \%$ to $1.0 \%$ when the temperature increased from $175^{\circ} \mathrm{C}$ to $975^{\circ} \mathrm{C}$.

The oxygen content of biochar from rice hulls significantly increased from $57 \%$ to $71 \%$ as the airflow increased, but there was no significant difference between the two insulation conditions (fig. 6a). Comparing figures $3 a$ and $6 a$, it can be seen that the trend of carbon content was contrary to that of oxygen content. As a result, the increase in oxygen content suggests a strong influence of oxidation reactions on the formation of carbon during the carbonization process, rather than aromatic carbon formation (Baldock and Smernik, 2002). In contrast, the oxygen content in the biochar from

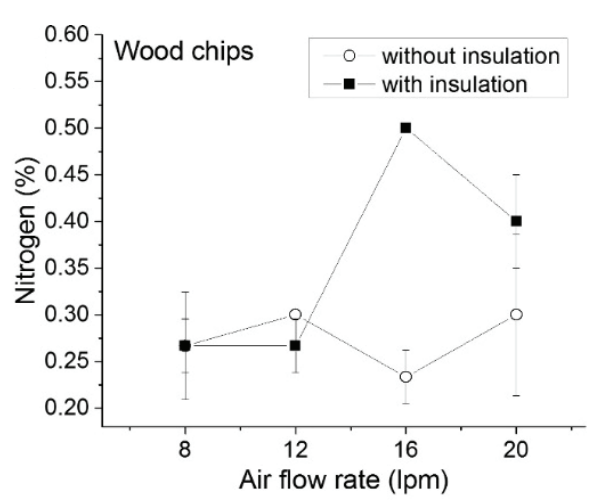

(b)

Figure 4. Elemental nitrogen composition in biochar produced from (a) rice hulls and (b) wood chips.

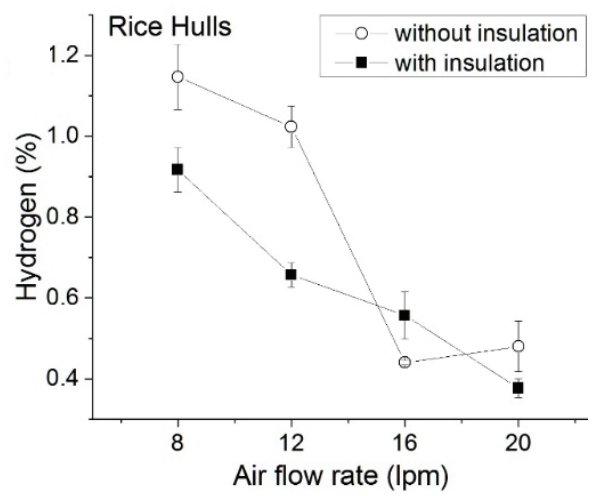

(a)

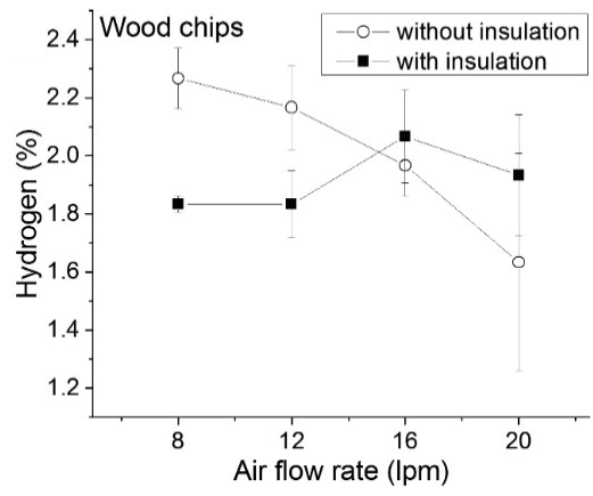

(b)

Figure 5. Elemental hydrogen composition in biochar produced from (a) rice hulls and (b) wood chips. 


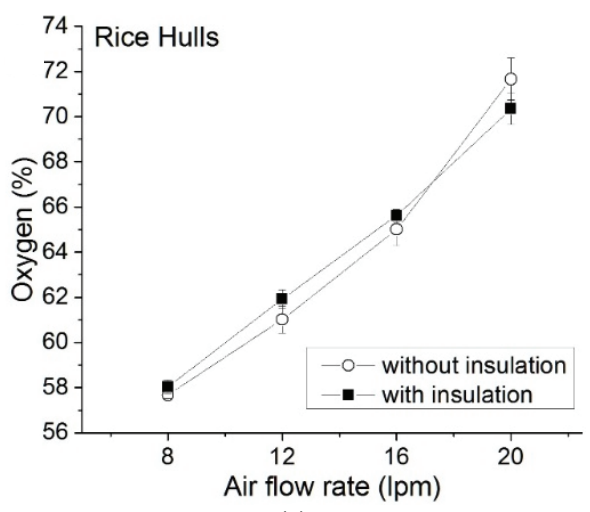

(a)

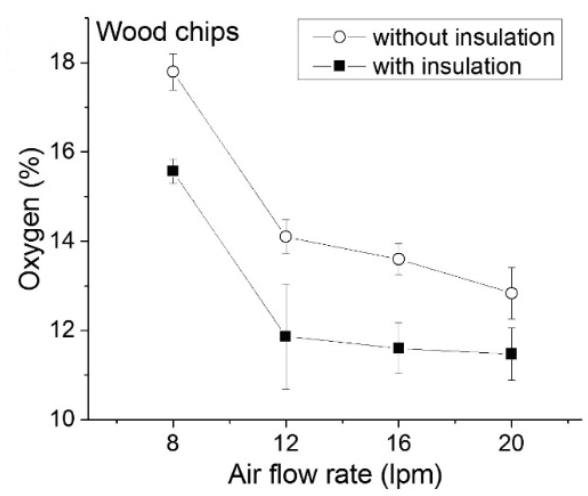

(b)

Figure 6. Elemental oxygen composition in biochar produced from (a) rice hulls and (b) wood chips.

wood chips exhibited noticeable decrease from $17.8 \%$ to $12.8 \%$ as the airflow increased from 8 to $20 \mathrm{~L} \mathrm{~min}^{-1}$ (fig. $6 \mathrm{~b}$ ). The biochar produced at $8 \mathrm{~L} \mathrm{~min}^{-1}$ was found to be significantly different in oxygen content from the biochar generated at higher airflows $\left(>12 \mathrm{~L} \mathrm{~min}^{-1}\right)$ regardless of the insulation condition. It is interesting that rice hull biochar had much higher oxygen content than woodchip biochar. This suggests that, contrary to the gasification of rice hulls, the gasification of wood chips presented a predominant level of aromatization that promoted the carbonization of aromatic components within the molecular structure of the biochar. The oxygen in the rice hull biomass was $49.90 \%$, while the wood chips contained only $11.50 \%$ to $17.80 \%$ oxygen. As a result, the biochar produced from biomass with high ash content can contain higher oxygen as the airflow increases due to the predomi-

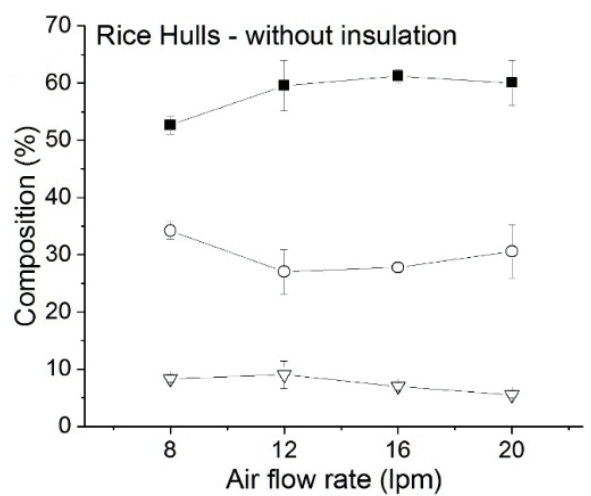

(a)

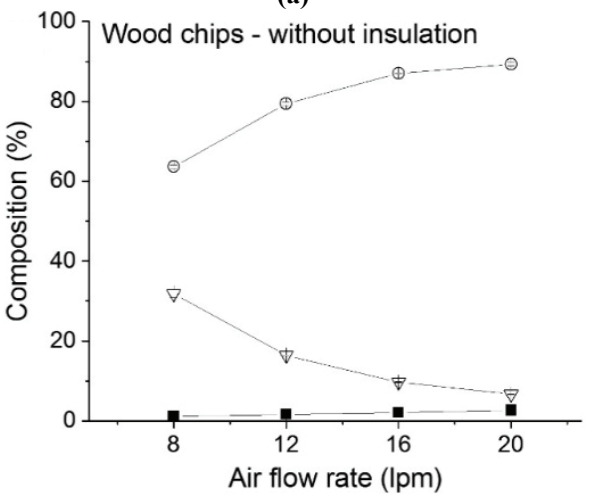

(c) nance of oxidation reactions during biochar formation. In contrast, low ash content in the biomass can promote reduction in biochar oxygen content when the airflow increases due to the dominating aromatization of the biochar.

\section{Proximate Analysis}

The average fixed carbon in rice hull biochar decreased from $34 \%$ to $23 \%$ as the airflow increased (figs. $7 \mathrm{a}$ and $7 \mathrm{~b}$ ). However, no statistically significant difference was found when the airflow and insulation were varied. In contrast, the fixed carbon in wood chip biochar significantly increased with increasing airflow (figs. 7c and 7d). The lowest fixed carbon content $(63.6 \%)$ was at $8 \mathrm{~L} \mathrm{~min}^{-1}$ without insulation, and the highest $(91.0 \%)$ was at $20 \mathrm{~L} \mathrm{~min}^{-1}$ with insulation. This increase in fixed carbon can be attributed to the overall increase in reaction temperature and the low ash content of

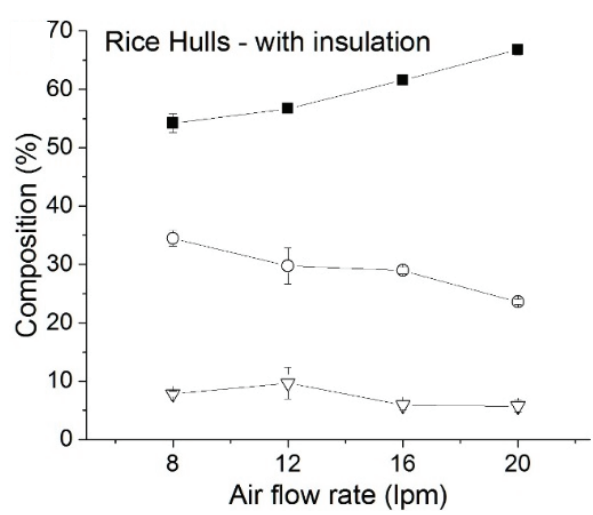

(b)

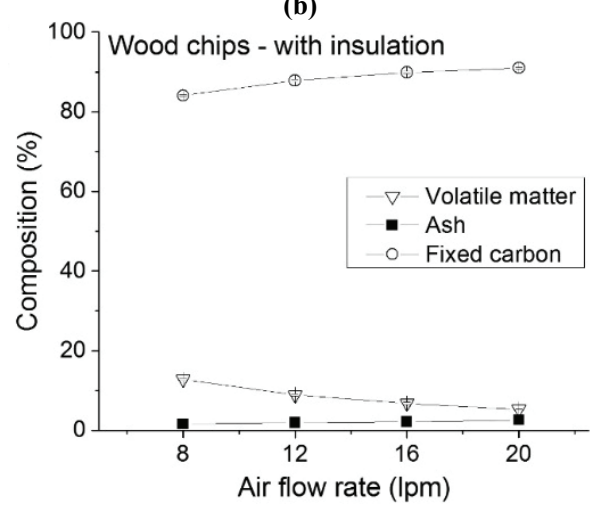

(d)

Figure 7. Proximate analyses of rice hull biochar (a) without and (b) with insulation and wood chip biochar (c) without and (d) with insulation. 
the unreacted biomass, similar to the tendency presented by the elemental carbon content of this biomass.

The gasification of rice hulls exhibited an increase in the ash content from $52.6 \%$ to $60.4 \%$ as the airflow increased with no insulation. Similarly, the ash content in the biochar increased from $54.2 \%$ to $66.8 \%$ when insulation was used. This phenomenon might be due to the fact that most ash components are minerals (Joseph et al., 2009) that might remain unreacted during gasification. However, carbon-based components such as tar and fixed carbon react when the temperature increases, which generates gases that are transported with the gas phase (Jameel et al., 2009). Therefore, the ash content in rice hulls $(23 \%)$ might be considered a fixed amount that appeared to increase when compared with the decreasing carbon content. Due to the low ash content, the carbon content in the wood chip biochar was not considerably impacted. Moreover, the ash content increased with increasing airflow. Despite this increase, the highest ash content derived from wood chips was $2.59 \%$ at $20 \mathrm{~L} \mathrm{~min}^{-1}$ (no insulation), which represented only $\sim 1.5 \%$ more ash when compared with the initial biomass (fig. 7c).

The volatile matter content of biochar from rice hulls varied between $5.5 \%$ and $9.6 \%$, which was significantly lower than that that of the unreacted rice hulls (figs. $7 \mathrm{a}$ and $7 \mathrm{~b}$ ). However, no significant difference was found in the volatile matter of biochar from rice hulls when comparing every level of airflow and insulation. Similarly, with increasing airflow, the volatile matter of wood chip biochar decreased from $31.8 \%$ to $6.6 \%$ without insulation and from $12.0 \%$ to $5.3 \%$ with insulation (figs. $7 \mathrm{c}$ and $7 \mathrm{~d}$ ). The combustion zone in top-lit updraft gasifiers is partially fueled by the volatiles released from the biomass below this zone in a process often known as flaming pyrolysis (Saravanakumar et al., 2007; Hangfu et al., 2014). This devolatilization phenomenon can be observed by comparing the initial volatiles in the biomass with those in the biochar; rice hulls initially contained $58 \%$ volatiles, and wood chips contained $74 \%$. As the airflow increased, more of the volatiles were removed because of the increasing reaction temperatures in the gasifier (fig. 2).

\section{HHV AND SPECIFIC SURFACE AREA}

The HHV results of the biochars are presented in figure 8 . The HHV of rice hull biochar from decreased from 14.9 to 9.5 $\mathrm{MJ} \mathrm{kg}{ }^{-1}$ without insulation and from 14.8 to $10.2 \mathrm{MJ} \mathrm{kg}^{-1}$ with

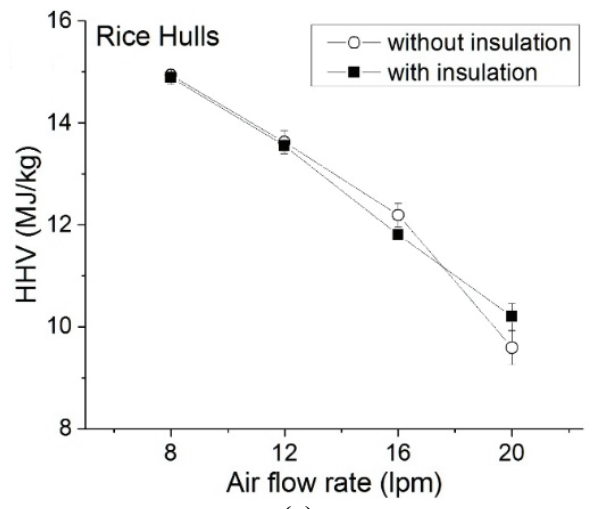

(a) insulation as the airflow increased (fig. 8a). Although the biochars produced at every airflow rate were significantly different, no significant differences were noticed when independent insulation conditions were evaluated at different airflows. In contrast, the HHV of wood chip biochar increased from 29.1 to $33.2 \mathrm{MJ} \mathrm{kg}^{-1}$ without insulation with increasing airflow (fig. 8b). However, no significant differences were seen in the HHV of the wood chip biochar with insulation, which varied from 32.1 to $33.2 \mathrm{MJ} \mathrm{kg}^{-1}$.

When comparing the heating values of the biomass with the heating value of the biochar, it can be seen that, other than the heating value at $8 \mathrm{~L} \mathrm{~min}^{-1}$, the rice hull biochar had a lower heating value than the initial biomass. Nonetheless, all biochars produced from wood chips yielded heating values higher than that of the biomass. This tendency can be attributed to the ash content of the biomass. Brewer (2012) converted corn stover, switchgrass, and hardwood into biochars using pyrolysis and gasification methods. The results showed that biomass types with high ash contents produced biochars with lower heating potential when compared to biomass with low ash content, which produced biochar with high heating potential. This suggests that the HHV of biochar is not only a result of the operating parameters during conversion but is also influenced by the chemical properties of the biomass. Comparing figures $8 \mathrm{~b}$ and $8 \mathrm{a}$, it is apparent that there was a large discrepancy between the insulated and non-insulated HHV at 8 and $12 \mathrm{~L} \mathrm{~min}^{-1}$ airflow for wood chips compared to rice hulls. This can be explained by figure 7, which shows that there was little or no difference in the composition of rice hull biochars produced with and without insulation. However, for wood chips, the differences in biochar composition with and without insulation were significant at 8 and $12 \mathrm{~L} \mathrm{~min}^{-1}$. Large differences in volatile and fixed carbon contents caused significant differences in the HHV of wood chip biochar.

The BET surface area results are presented in figure 9. The biochar produced from rice hulls showed an increase in the surface area from 1.7 to $30.4 \mathrm{~m}^{2} \mathrm{~g}^{-1}$ without insulation and from 9.4 to $183.0 \mathrm{~m}^{2} \mathrm{~g}^{-1}$ with insulation as the airflow increased from 8 to $20 \mathrm{~L} \mathrm{~min}^{-1}$ (fig. 9a). The BET surface area of wood chip biochar increased from 1.5 to $332.0 \mathrm{~m}^{2} \mathrm{~g}^{-1}$ without insulation and from 56.0 to $405.0 \mathrm{~m}^{2} \mathrm{~g}^{-1}$ with insulation. This increase in the BET surface area of both biomass types was correlated with the combustion temperature of the gasification reaction. When the airflow increased from 8 to $20 \mathrm{~L}$

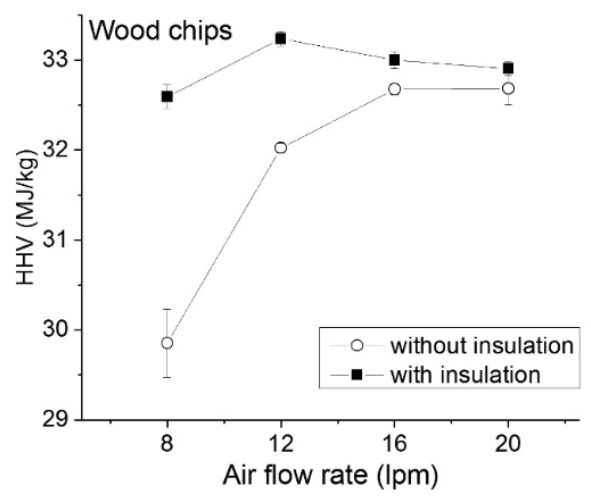

(b)

Figure 8. Higher heating value (HHV) of biochar produced from (a) rice hulls and (b) wood chips. 


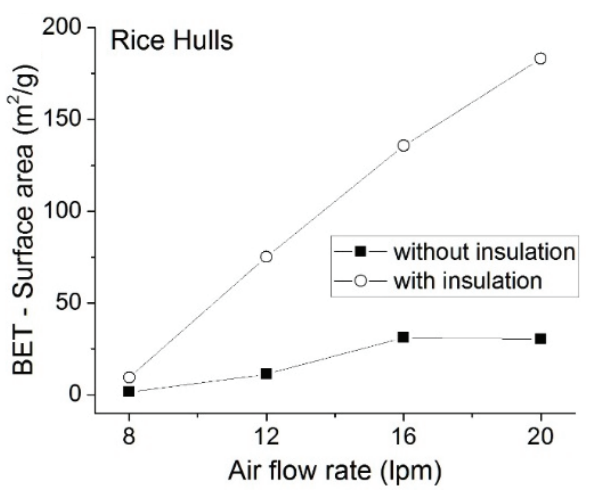

(a)

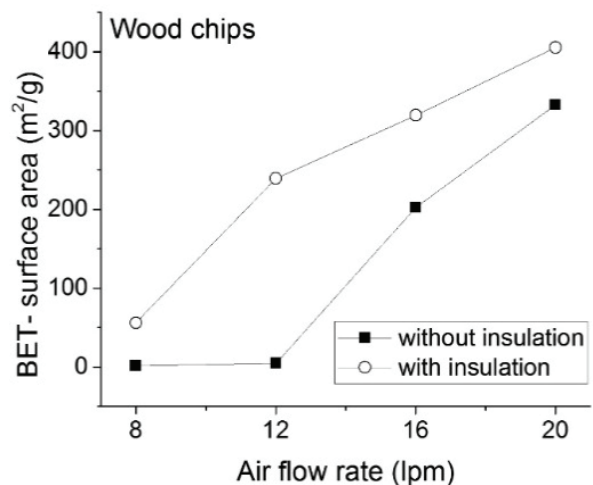

(b)

Figure 9. BET surface area of biochar produced from (a) rice hulls and (b) wood chips.

$\min ^{-1}$ without insulation, the combustion temperature increased from $700^{\circ} \mathrm{C}$ to $862^{\circ} \mathrm{C}$, which presented a linear correlation with an adjusted $\mathrm{R}^{2}$ of 0.80 . With the addition of insulation, the temperature increased from $714^{\circ} \mathrm{C}$ to $868^{\circ} \mathrm{C}$ with an adjusted $\mathrm{R}^{2}$ of 0.99 . Similarly, the BET surface area of wood chip biochar was correlated with the combustion temperature increase from $648^{\circ} \mathrm{C}$ to $815^{\circ} \mathrm{C}$ with an adjusted $\mathrm{R}^{2}$ of 0.65 without insulation, and with the combustion temperature increase from $661^{\circ} \mathrm{C}$ to $840^{\circ} \mathrm{C}$ with an adjusted $\mathrm{R}^{2}$ of 0.99 with insulation.

The increase in overall reaction temperature as a result of the addition of insulation had a positive effect on the BET surface area. A similar increase in BET surface area was reported by Peterson (2014) when increasing the temperature of a pyrolysis unit from $400^{\circ} \mathrm{C}$ to $700^{\circ} \mathrm{C}$. The results showed that the surface area of biochar from corn stover increased from 18 to $451 \mathrm{~m}^{2} \mathrm{~g}^{-1}$. Likewise, Lua et al. (2004) studied the effect of temperature on the pyrolysis of pistachio nut shells. As the reaction temperature increased from $250^{\circ} \mathrm{C}$ to $1000^{\circ} \mathrm{C}$, the BET surface area of the biochar increased from 333 to $601 \mathrm{~m}^{2} \mathrm{~g}^{-1}$, which was attributed to evacuation of micropores within the biochar structure. This indicated that a proportional increase in combustion temperature because of increased airflow and the addition of insulation could promote an increase in the BET surface area of the biochar produced by top-lit gasification regardless of the biomass type. In this study, biochar from wood chips showed much higher surface areas when compared with rice hulls. Biochar derived from woody biomass has been found to produce larger surface areas when compared with biochar from agricultural crops and grasses (Downie et al., 2009). This tendency has been previously associated with the lower ash content of woody biomass, which corresponds to a more carbon-based composition (Sun et al., 2014; Qian et al., 2013).

\section{CONCLUSION}

The properties of biochar produced in a top-lit updraft gasifier were strongly affected by an increase in airflow. However, different effects were observed for the different biomass types. Rice hull biochar showed significant decreases in the carbon, hydrogen, nitrogen, and fixed carbon contents and HHV as the airflow increased, but the oxygen content increased with increasing airflow. This was related to the high ash content of rice hulls and the oxidation of the gasification process. In contrast, wood chip biochar showed increases in the carbon and fixed carbon contents and HHV as the airflow increased. Moreover, the addition of insulation maximized the increase in biochar carbon content for biomass with low ash content (wood chips) because of the increasing aromaticity as the overall reaction temperature increased. However, adding insulation did not significantly affect the carbonization of biomass with high ash content (rice hulls). The volatile matter was significantly lower in the biochar than in the unreacted biomass. This was because of the consumption of volatiles in the combustion reactions. In addition, the BET surface area of the biochar was found to increase with increasing airflow and additional insulation regardless of the biomass type. Biochar from wood chips presented much higher BET surface area than that of rice hulls. Furthermore, the addition of insulation resulted in further increases in BET surface area because of the increased overall reaction temperature within the gasifier.

\section{ACKNOWLEDGEMENTS}

This material was based on the work supported by the USDA and Sun Grant (Award No. 2010-38502-21836 and Subaward No. AB-5-67630, KSU11) and the startup fund of North Carolina State University. This work was supported by the USDA National Institute of Food and Agriculture, Hatch Project NC02394. The lead author was also partially supported by the scholarship program of IFARHU-SENACYT from the Government of Panama. We would like to thank Mr. Justin Macialek, research assistant at NCSU, for his help building the top-lit updraft gasifier.

\section{REFERENCES}

Amonette, J. E., \& Joseph, S. (2009). Characteristics of biochar: Microchemical properties. In Biochar for environmental management: Science and technology (pp. 33-52). London, U.K.: Earthscan.

Antal, M. J., \& Grønli, M. (2003). The art, science, and technology of charcoal production. Ind. Eng. Chem. Res., 42(8), 1619-1640. http://dx.doi.org/10.1021/ie0207919

Antal, M. J., Croiset, E., Dai, X., DeAlmeida, C., Mok, W. S., Norberg, N., ..., Al Majthoub, M. (1996). High-yield biomass charcoal. Energy Fuels, 10(3), 652-658. http://dx.doi.org/10.1021/ef9501859

Antal, M. J., Mok, W. S., Varhegyi, G., \& Szekely, T. (1990). Review of methods for improving the yield of charcoal from 
biomass. Energy Fuels, 4(3), 221-225.

http://dx.doi.org/10.1021/ef00021a001

ASTM. (2011). D3175-11: Standard test method for volatile matter in the analysis sample of coal and coke. West Conshohocken, Pa.: ASTM. http://dx.doi.org/10.1520/D3175-11

ASTM. (2015). E1755-01: Standard test method for ash in biomass. West Conshohocken, Pa.: ASTM.

Baldock, J. A., \& Smernik, R. J. (2002). Chemical composition and bioavailability of thermally altered Pinus resinosa (red pine) wood. Organic Geochem., 33(9), 1093-1109. http://dx.doi.org/10.1016/S0146-6380(02)00062-1

Birzer, C., Medwell, P., Wilkey, J., West, T., Higgins, M., MacFarlane, G., \& Read, M. (2013). An analysis of combustion from a top-lit up-draft (TLUD) cookstove. J. Humanitarian Eng., 2(1), 1-8.

Brewer, C. E. (2012). Biochar characterization and engineering. Ames, Iowa: Iowa State University, Department of Chemical Engineering.

Brick, S., \& Lyutse, S. (2010). Biochar: Assessing the promise and risks to guide U.S. policy. Chicago, Ill.: Natural Resources Defense Council. Retrieved from www.nrdc.org/energy/files/biochar_paper.pdf

Bridgwater, A. V. (2012). Review of fast pyrolysis of biomass and product upgrading. Biomass Bioenergy, 38, 68-94. http://dx.doi.org/10.1016/j.biombioe.2011.01.048

Brown, R. (2009). Biochar production technology. In Biochar for environmental management: Science and technology (pp. 127146). London, U.K.: Earthscan.

Demirbas, A. (2001). Carbonization ranking of selected biomass for charcoal, liquid, and gaseous products. Energy Conv. Mgmt., 42(10), 1229-1238. http://dx.doi.org/10.1016/S01968904(00)00110-2

Demirbas, A. (2004). Effects of temperature and particle size on biochar yield from pyrolysis of agricultural residues. J. Anal. Appl. Pyrolysis, 72(2), 243-248. http://dx.doi.org/10.1016/j.jaap.2004.07.003

Downie, A., Crosky, A., \& Munroe, P. (2009). Physical properties of biochar. In Biochar for environmental management: Science and technology (pp. 13-32). London, U.K.: Earthscan.

Garcia-Perez, M., Lewis, T., \& Kruger, C. (2010). Methods for producing biochar and advanced biofuels in Washington State, Part 1: Literature review of pyrolysis reactors. Ecology Publication No. 11-07-017. Olympia, Wash.: Washington State Department of Ecology. Retrieved from https://fortress.wa.gov/ecy/publications/documents/1107017.pdf

Hu, S., Xiang, J., Sun, L., Xu, M., Qiu, J., \& Fu, P. (2008). Characterization of char from rapid pyrolysis of rice husk. Fuel Proc. Tech., 89(11), 1096-1105. http://dx.doi.org/10.1016/j.fuproc.2008.05.001

Huangfu, Y., Li, H., Chen, X., Xue, C., Chen, C., \& Liu, G. (2014). Effects of moisture content in fuel on thermal performance and emission of biomass semi-gasified cookstove. Energy Sustain. Devel., 21, 60-65. http://dx.doi.org/10.1016/j.esd.2014.05.007

Jameel, H., Keshwani, D. R., Carter, S., \& Treasure, T. H. (2009). Thermochemical conversion of biomass to power and fuels. In J. Cheng (Ed.), Biomass to renewable energy processes (pp. 437489). Boca Raton, Fla.: CRC Press.

Joseph, S., Peacocke, C., Lehmann, J., \& Munroe, P. (2009). Developing a biochar classification and test methods. In Biochar for environmental managenement: Science and technology (pp. 107-126). London, U.K.: Earthscan.

Kammen, D. M., \& Lew, D. J. (2005). Review of technologies for the production and use of charcoal. Renewable and appropriate energy laborator report. Berkley, Cal.: University of California. Retrieved from http://rael.berkeley.edu/old_drupal/sites/default/files/old-site-
files/2005/Kammen-Lew-Charcoal-2005.pdf

Kim, K. H., Kim, J., Cho, T., \& Choi, J. W. (2012). Influence of pyrolysis temperature on physicochemical properties of biochar obtained from the fast pyrolysis of pitch pine (Pinus rigida). Bioresour. Tech., 118, 158-162. http://dx.doi.org/10.1016/j.biortech.2012.04.094

Kwapinski, W., Byrne, C. M., Kryachko, E., Wolfram, P., Adley, C., Leahy, J., ..., Hayes, M. (2010). Biochar from biomass and waste. Waste Biomass Valor., 1(2), 177-189. http://dx.doi.org/10.1007/s12649-010-9024-8

Lehmann, J., \& Joseph, S. (2009). Biochar for environmental management: An introduction. In Biochar for environmental management: Science and technology (pp. 1-12). London, U.K.: Earthscan.

Lua, A. C., Yang, T., \& Guo, J. (2004). Effects of pyrolysis conditions on the properties of activated carbons prepared from pistachio nut shells. J. Anal. Appl. Pyrolysis, 72(2), 279-287. http://dx.doi.org/10.1016/j.jaap.2004.08.001

Manyà, J. J. (2012). Pyrolysis for biochar purposes: A review to establish current knowledge gaps and research needs. Environ. Sci. Tech., 46(15), 7939-7954. $\mathrm{http} / / / \mathrm{dx}$. doi.org/10.1021/es301029g

Mukunda, H., Dasappa, S., Paul, P., Rajan, N., Yagnaraman, M., Ravi Kumar, D., \& Deogaonkar, M. (2010). Gasifier stoves: Science, technology, and field outreach. Current Sci., 98(5), 627-638.

Peterson, S. C., \& Jackson, M. A. (2014). Simplifying pyrolysis: Using gasification to produce corn stover and wheat straw biochar for sorptive and horticultural media. Ind. Crops Products, 53, 228-235. http://dx.doi.org/10.1016/j.indcrop.2013.12.028

Qian, K., Kumar, A., Patil, K., Bellmer, D., Wang, D., Yuan, W., \& Huhnke, R. L. (2013). Effects of biomass feedstocks and gasification conditions on the physiochemical properties of char. Energies, 6(8), 3972-3986. http://dx.doi.org/10.3390/en6083972

Reed, T., \& Larson, R. (1997). A wood-gas stove for developing countries. In Developments in thermochemical biomass conversion (pp. 985-993). New York, N.Y.: Springer.

Saravanakumar, A., Haridasan, T., Reed, T. B., \& Bai, R. K. (2007). Experimental investigation and modelling study of long-stick wood gasification in a top-lit updraft fixed bed gasifier. Fuel, 86(17), 2846-2856. http://dx.doi.org/10.1016/j.fuel.2007.03.028

Shackley, S., Carter, S., Knowles, T., Middelink, E., Haefele, S., Sohi, S., ..., Haszeldine, S. (2012). Sustainable gasificationbiochar systems? A case study of rice husk gasification in Cambodia, Part I: Context, chemical properties, environmental and health and safety issues. Energy Policy, 42, 49-58. http://dx.doi.org/10.1016/j.enpol.2011.11.026

Sun, Y., Gao, B., Yao, Y., Fang, J., Zhang, M., Zhou, Y., ..., Yang, L. (2014). Effects of feedstock type, production method, and pyrolysis temperature on biochar and hydrochar properties. Chem. Eng. J., 240, 574-578. http://dx.doi.org/10.1016/j.cej.2013.10.081

Trossero, M., Domac, J., \& Siemons., R. (2008). Industrial charcoal production. TCP/CRO/3101(A). Rome, Italy: United Nations FAO. Retrieved from $\mathrm{http} / /$ pvbiochar.org/forum/index.php?action=dlattach;topic $=133$ 5.0; attach $=234$

Tryner, J., Willson, B. D., \& Marchese, A. J. (2014). The effects of fuel type and stove design on emissions and efficiency of natural-draft semi-gasifier biomass cookstoves. Energy Sustain. Devel., 23, 99-109. http://dx.doi.org/10.1016/j.esd.2014.07.009

Warnecke, R. (2000). Gasification of biomass: Comparison of fixed bed and fluidized bed gasifier. Biomass Bioenergy, 18(6), 489497. http://dx.doi.org/10.1016/S0961-9534(00)00009-X 